\title{
The Impact of Climate Change on Cooling Energy Demand in Indonesia Based on Representative Concentration Pathways (RCP) Scenarios
}

\author{
Desak Putu Okta Veanti ${ }^{1 *}$, Rista Hernandi Virgianto1', I Gusti Ayu Putu Putri Astiduari² \\ ${ }^{1}$ Department of Climatology, School of Meteorology Climatology and Geophysics, Jakarta, 15221, Indonesia \\ ${ }^{2}$ Department of Meteorology, School of Meteorology Climatology and Geophysics, Jakarta, 15221, Indonesia \\ *Corresponding author: okta.veanti@stmkg.ac.id
}

\begin{abstract}
Air conditioning system in a building is necessary to maintain air temperature at a certain comfort level, especially in tropical countries such as Indonesia. Global warming was believed to accelerate the increase in energy consumption for air conditioning as a consequence of rising surface temperatures. This study aims to quantify the changes in energy consumption used for air conditioning systems based on Cooling Degree Days (CDD) that is calculated from the daily average temperature in Indonesia based on RCP4.5 and RCP8.5 scenarios. Projections for the future scenarios is compared with the energy consumptions in 2010. The results showed that energy consumptions increase up to $10 \mathrm{kWh} / \mathrm{m}^{2}$ year in 2030 for both scenarios. In $2050 \mathrm{RCP} 4.5$ shows slightly higher $\mathrm{E}_{w}$ than RCP8.5 in some regions. However, in 2100, RCP8.5 shows significantly higher energy consumption for air conditioning system. The eastern part of Middle Kalimantan, South Kalimantan, Southern part of East Kalimantan, Northern East Java, Northern part of Lampung, South Sumatera, and Southern part of Papua shows the highest changes ( 51 to $68 \mathrm{kWh} / \mathrm{m}^{2}$ year)
\end{abstract}

\section{Keywords}

Air conditioning, Cooling degree day, Global Warming, Surface temperature, Climate scenario

\section{INTRODUCTION}

A comfortable temperature for housing is one of the main human needs. As time goes on, there is an increase in the standards of satisfaction followed by an increase in the use of heating and cooling device. As the increase in GDP, more people in Indonesia demand more comfortable temperature for their housing. James $(2008)$ states that the main use of energy in a building for heating, cooling, and ventilating contributing a total $43 \%$ of the building energy demand. The energy demand for air conditioning system is necessary to maintain a room in comfortable temperature. Since Indonesia is located in Tropical area, air cooling systems are often used in housing especially during warm and sunny days. The demand from office buildings is even higher because they use the air-cooling systems more than household needs in daily basis.

According to Kementerian Energi dan Sumber Daya Mineral (2018), the requirement of electrical energy has reached $1.02 \mathrm{GWh} /$ capita in 2017 or $5.9 \%$ higher compared to previous year. From the total users of electrical energy, household group is the largest group of users who contribute in the use of $91.88 \%$ of the total electric energy. Based on the explanation from the Executive Director of the International Energy
Agency (IEA), Fatih Birol, world electricity use will be even higher, which is triggered by the use of air conditioning. From this explanation, we are interested in the use of air conditioning in Indonesia and the amount of energy this country consumes each year.

The next issue related to energy for cooling system is climate change. Temperature on land and sea show an increase of around $0.65^{\circ} \mathrm{C}$ to $1.06^{\circ} \mathrm{C}$ between $1880-2012$, and it is estimated that greenhouse gases will cause sustainable heating with a temperature increase of $0.3^{\circ} \mathrm{C}$ to $4.8^{\circ} \mathrm{C}$ from $2081-2100$ (Stocker, 2014; Intergoverment Panel Climate Change, 2013). Warmer weather means the demand for cooling energy will increase since the energy consumption and temperature is closely related (National Bureau of Statistics of China, 2013).

The relationship between temperature and cooling energy demand can be explained by a simple concept, Cooling Degree Days (CDD). CDD is a basic quantity for estimating energy consumption of building for cooling based on the air temperature of the environment around the building or houses (Assawamartbunlue, 2013). This concept was developed by Thom (1952); Thom (1954) it is easy to use and quite practical in calculating the energy needed for cooling. The concept 
is already widely used in many research (Thevenard , 2011; Siyak , 2009; Atalla et al., 2018; Spinoni et al., 2018). One example is the research conducted by Spinoni et al. (2018) which use CDD and HDD concept to analyses its change from 1981 to 2100. It was applied to EURO-CORDEX data and able to explain the trend and its climate conditions. Next is the research conducted in Libya to calculate the annual heating and cooling energy in requirements for residential building (Bodalal et al., 2017).

In this study, the concept will be applied on Coordinated Regional Climate Downscaling Experiment (CORDEX) for South East Asia Region (CORDEX-SEA) (Tangang et al., 2015). The data provide us with high resolution Climate Change Scenario, therefore it would improve the quality of research related to climate change. The application of CORDEX-SEA dataset on research varied widely. It was used in studying the change in rainfall and its extreme (Tangang et al. , 2020; Ngo-Duc et al., 2017). The other research from Nguyen-Thuy et al. (2021) used CORDEX-SEA dataset to detect time of emergence of climate signal. The main goal in this paper is to apply the concept of CDD to calculate the energy demand based on Representative Concentration Pathways (RCP) scenarios in Indonesia and to find out the change in $\mathrm{CDD}$ and energy demand in the near future (2050) and far future (2100).

\section{EXPERIMENTAL SECTION}

\subsection{Research Area and Datasets}

The research area in this study is limited to Indonesia area in the coordinates of $88^{\circ} \mathrm{E}-144^{\circ} \mathrm{E}$ and $10^{\circ} \mathrm{N}-14^{\circ} \mathrm{S}$. Part of Malaysia which is located in Kalimantan Island and Brunei Darussalam is included in study area to see the whole picture of Kalimantan Island. Without those, the results might be misleading because we cannot see the overall topography of the island. The research area is located in tropics, consists of more than 13,000 islands with 5 biggest islands which are Sumatera, Java, Kalimantan, Sulawesi, and Papua. We should note that some islands are too small to be shown on the map.

Data used is dataset resulted from Southeast Asia Regional Climate Downscaling (SEACLID) which is also known as Coordinated Regional Climate Downscaling Experiment for South East Region (CORDEX-SEA) (Tangang et al., 2015). Data used is daily surface temperature and consists of historical from 1951-2005, RCP4.5 and RCP8.5 data from 2006-2100. Before using the data, we compare the data with observational data from Pondok Betung Climatological Station, located at $106.76^{\circ} \mathrm{E}$ and $6.25^{\circ} \mathrm{S}$. The length of observational data is from 1979 until today. However, because we only compare historical data, we only use the data from 1979-2005.

Figure la shows the time series of monthly temperature from observational data and CORDEX-SEA historical data. It is shown that CORDEX-SEA has similar monthly temperature to observational data. The seasonal cycle is also can be explained by CORDEX-SEA. However, in the period before 1992, CORDEX-SEA tend to be overestimate to the monthly temperature, while in the period after 1992, it is the other way

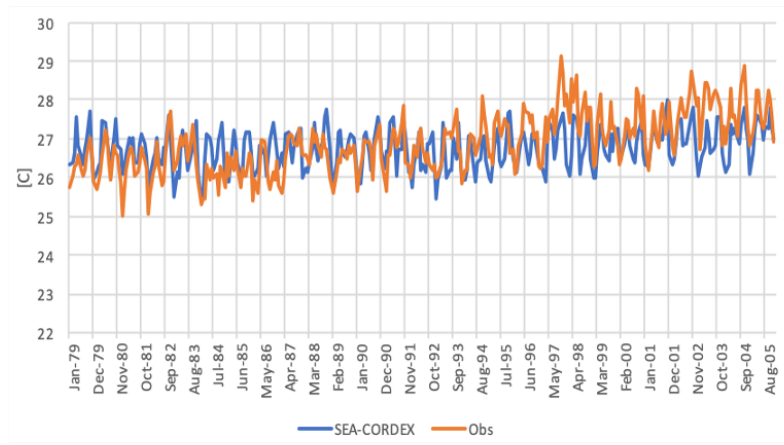

(a)

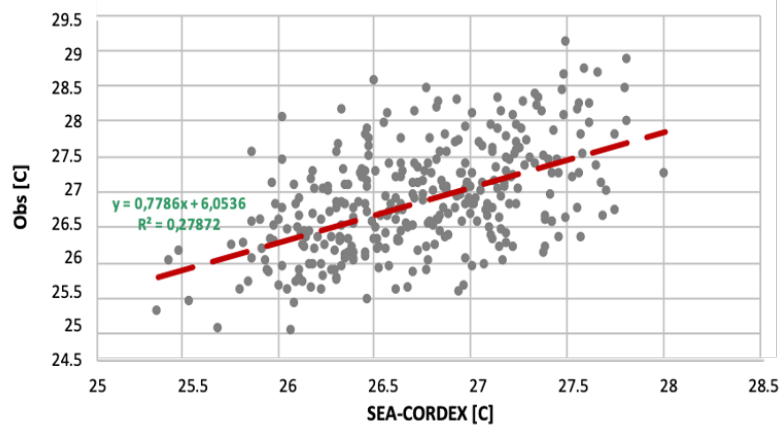

(b)

Figure 1. (a) The Scatter Plot of Observational Data and CORDEX-SEA Data from 1979-2005, (b) Time Series Monthly Observational Data and CORDEX-SEA Data from 1979-2005

around. This is because CORDEX-SEA underestimate the real trend of temperature in Pondok Betung Climatological Station, Jakarta.

The relationship between monthly temperature data from observation and CORDEX-SEA can be seen in Figure 1b The scatter plot shows that CORDEX-SEA explained $27.9 \%$ of observational data. The correlation coefficient between the two dataset is 0.53 with $\mathrm{p}$-value $=0$. It means CORDEX-SEA data has significant positive relationship with observational data. Mean absolute error and root mean square error was calculated, resulting the value of 0.53 and 0.66 respectively. Therefore, temperature from CORDEX-SEA dataset is good enough to represent the real condition.

\subsection{Methods}

In this study, CDD concept is applied to CORDEX-SEA data to find out how much the energy needed to keep a space in its most comfortable temperature. CDD is calculated based on Rehman et al. (2011) calculation. It is results from subtracting the daily averaged near surface temperature $\left(T_{d}\right)$ with the base temperature $\left(\mathrm{T}_{b}\right)$. In this study, daily $2 \mathrm{~m}$ temperature data from CORDEX-SEA is used to represent averaged near surface temperature $\left(\mathrm{T}_{d}\right)$. Base temperature is the temperature in which a space no longer needs cooling. It is simply the tem- 
perature which is wanted or the most comfortable temperature people want to keep. If the temperature of environment is higher than the base temperature, it means some amount of energy will be needed to cool the space. The higher the gap between environmental temperature and the base temperature, the more energy will be needed.

Most studies use $18^{\circ} \mathrm{C}\left(65^{\circ} \mathrm{F}\right)$ for the $\mathrm{T}_{b}$ such as study from Shanmugapriya et al. (2011) that researched the CDD for Tiruchirappalli in India, and Wibig (2003) about HDD and CDD variability in Lodz of Poland in the period 1931-2000. However, all those studies are done in the extratropical regions. In tropics, people already get used to warmer temperature, therefore it does make sense that Indonesian will demand higher $\mathrm{T}_{b}$. Hence, we found other standard for $\mathrm{T}_{b}$ which is the regulation of the Ministry of Energy and Mineral Resources of Republic Indonesia Number 13 of 2012 concerning The Saving of Electricity Use. In Chapter II concerning The Implementation of Electricity Saving, Article 4 Paragraph 6 which regulates the temperature of air conditioning use. Based on the decree, $22^{\circ} \mathrm{C}-24^{\circ} \mathrm{C}$ is the base temperature and, in this study, we use $24^{\circ} \mathrm{C}$ as the base temperature (Intergoverment Panel Climate Change, 2014a; Intergoverment Panel Climate Change, 2014b). The energy consumption is calculated based on Cooling Degree Days (CDD) that calculated by subtracting the $\mathrm{T}_{d}$ with $\mathrm{T}_{b}$ mentioned (Buyunakalaca et al., 2001; Rehman et al., 2011).

$$
C D D=T_{d}-T_{b}
$$

Equation 1 is used to calculate the value of a daily CDD and then accumulated the value for a certain period. We calculate the seasonal and annual CDD values explained by Equation 2 (Rehman et al., 2011).

$$
A C D D=\sum_{i=1}^{N} C D D_{i}\left\{\begin{aligned}
T_{d}>T_{b}, & \text { then } & C D D & =T_{d}-T_{b} \\
& \text { if not } & C D D & =0
\end{aligned}\right.
$$

with: $\mathrm{ACDD}=$ accumulated cooling degree days, $\mathrm{CDD}=$ cooling degree days, $\mathrm{T}_{d}=$ daily averaged near-surface temperature, $\mathrm{T}_{b}=$ base temperature, $\mathrm{N}=$ number of days in certain period.

The total energy consumption for air cooling system $\left(\mathrm{E}_{w}\right)$ is calculated by following equation (Bodalal et al., 2017)

$$
E_{w}=\frac{Q_{w}}{C_{o p}}
$$

with: $Q_{w}=$ heat transmission that penetrates the surface of building $\left(\mathrm{kWh} / \mathrm{m}^{2}\right), \mathrm{C}_{o p}=$ coefficient of air cooling system performance.

Heat transmission that penetrates the building surface can be calculated using the following equation (Bodalal et al., 2017)

$$
Q_{w}=0.024 x U_{o} \times C D D
$$

$$
U_{o}=\frac{1}{R_{w t}}
$$

with: $\mathrm{U}_{o}=$ heat transfer coefficient without insulation $\left(\mathrm{W} / m^{2}{ }^{\circ} \mathrm{C}\right)$, $\mathrm{CDD}=$ Cooling Degree-Days $\left({ }^{\circ} \mathrm{C}\right), \mathrm{R}_{w t}=$ thermal resistance of the wall $\left(\mathrm{m}^{2 \circ} \mathrm{C} / \mathrm{W}\right)$

$\mathrm{U}_{o}$ is used because most buildings in Indonesia is without insulation, without the addition of insulation, the radiation between $\mathrm{CDD}$ and Energy demand $\left(\mathrm{E}_{w}\right)$ is linear where to cool $1{ }^{\circ} \mathrm{C}$ CDD, $0.272727 \mathrm{kWh}$ energy is needed. Rwt is the thermal resistance of the wall that is $0.44 \mathrm{~m}^{2}{ }^{\circ} \mathrm{C} / \mathrm{W}$ so that the Uo value or the heat transfer coefficient without insulation is $2.2727 \mathrm{~W} / \mathrm{m}^{2}{ }^{\circ} \mathrm{C}$. Cop is the coefficient of performance of the AC cooling system and is assumed to be equal as 2 (Bodalal et al., 2017).

To study the influence of climate change on energy demand for cooling, we use two RCP scenarios. RCP is the latest generation of scenarios that provide input to climate models. Both scenarios are available in CORDEX-SEA data. RCP4.5 (intermediate emission) is a scenario which stabilizes radiative forcing at $4.5 \mathrm{~W} / \mathrm{m}^{2}$ in the year 2100 without ever exceeding that value (Thomson et al., 2011). RCP8.5 (high emission) is consistent with a future with no policy changes to reduce emission is characterized by increasing greenhouse gas emission that leads to high greenhouse gas concetration overtime. Increase of global mean surface temperatures for 2081-2100 relative to $1986-2005$ is projected to likely be in the ranges derived from the concentration driven CMIP5 model simulations, that is $1.1^{\circ} \mathrm{C}$ to $2.6^{\circ} \mathrm{C}$ for $\mathrm{RCP} 4.5$ and $2.6^{\circ} \mathrm{C}$ to $4.8^{\circ} \mathrm{C}$ for RCP8.5.

\section{RESULTS AND DISCUSSION}

\subsection{Present Condition, Spatial Analysis of CDD and $\mathrm{E}_{w}$ from 1951-2005}

After applying CDD concept and Bodalal et al. (2017) method on CORDEX-SEA historical data, maps of energy demand for cooling are derived. It is shown in Figure $2 \mathrm{a}$ and $2 \mathrm{~b}$. Figure $2 \mathrm{a}$ shows the mean yearly accumulated CDD over Indonesia from 1951-2005. It was the result of accumulating CDD for each year then calculating the mean for the period of 1951-2005. Note that the quantities will be explained in degree-days.

From the map, it is clear that CDD over Indonesia is highly related to its topography. The coastal area tends to have higher CDD values while the mountains and highland tend to have lower CDD. Other factors such as difference in latitude does not show obvious effect because Indonesia lays on a narrow band of tropical region and its area stretch wider from west to east. Coastal area and lowland tend have more than $700^{\circ} \mathrm{C} /$ year while higher places have CDD less than $700^{\circ} \mathrm{C} /$ year.

Some places have very high yearly accumulated CDD (more than $1400^{\circ} \mathrm{C}$ /year). It is found on small islands such as Nias island and Siberut island that located in the West of Sumatera Island, Eastern coast of Madura and some small islands around 


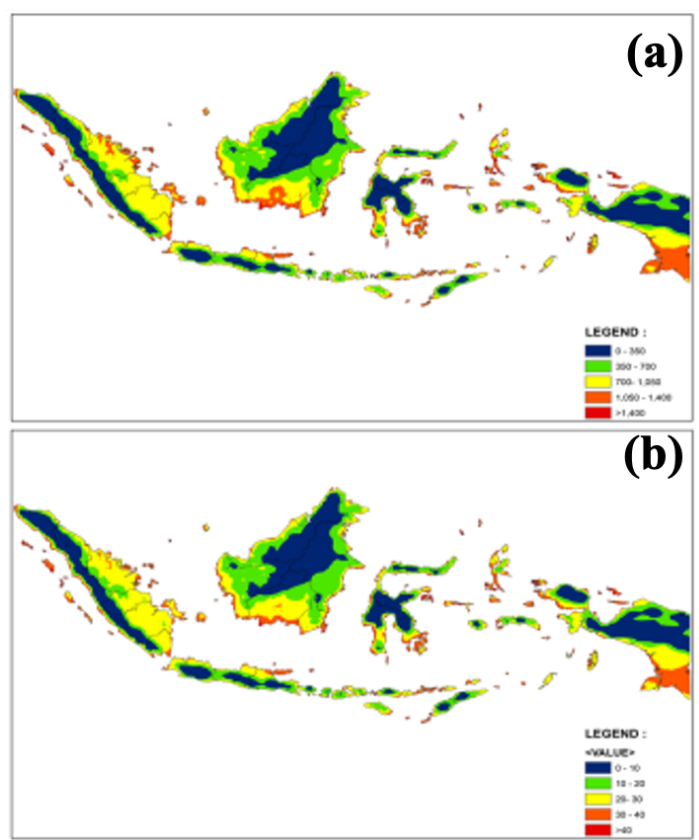

Figure 2. (a) The CDD Average Year from 1951-2005, (b) The $\mathrm{E}_{w}$ Average Year from 1951-2005

it, Peleng island in the East of Sulawesi Island and in some spots on Maluku islands. This value can be found in the Southern coast of Kalimantan too.

$\mathrm{E}_{w}$ shows similar pattern with CDD map because its relationship is linear. Lowlands and coastal areas tend to have $\mathrm{E}_{w}$ more than $20 \mathrm{kWh} / \mathrm{m}^{2}$ year while higher lands and mountains have $\mathrm{E}_{w}$ less than $20 \mathrm{kWh} / \mathrm{m}^{2}$ year. This means people who live in lowland and coastal area need more energy for cooling. The fact that most population live in the lowland and coastal regions make it important to consider that most people need high amount of energy for cooling their houses and buildings. The value of CDD might be influenced by urban heat effect too, similar to study in Bandung (Arifwidodo et al., 2019; Arifwidodo et al., 2021)

\subsection{Future Condition, Time Series Analysis of CDD and $\mathbf{E}_{w}$}

After calculation of CDD and $\mathrm{E}_{w}$, two grid point is picked to see the examples of how the time series of CDD and $\mathrm{E}_{w}$ look like. One grid point represents the coastal area and lowland $\left(106.69^{\circ} \mathrm{E}\right.$ and $6.15^{\circ} \mathrm{S}$, in Tangerang Selatan-Tangsel). The other grid point represents highland $\left(106.91^{\circ} \mathrm{E}\right.$ and $6.82^{\circ} \mathrm{S}$, close to Pangrango Mountain-Pangrango). Time series of CDD and $\mathrm{E}_{w}$ of the chosen grid points are shown in Figure $3 \mathrm{a}$ and $3 \mathrm{~b}$.

CDD graph from 1951-2100 is shown on Figure 3a, Pangrango shows pronounced lower CDD comparing to Tangsel Grid. However, both grids have similar line shape. Baseline data from 1951-2005 does not show pronounced trend. The CDD at Tangsel is around 1,000 degree-days in this time pe-

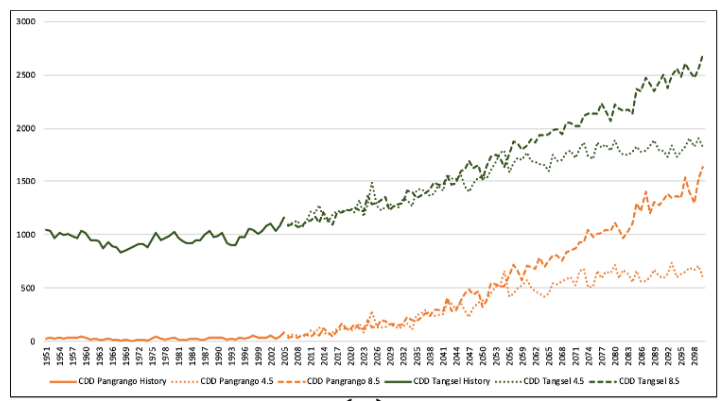

(a)

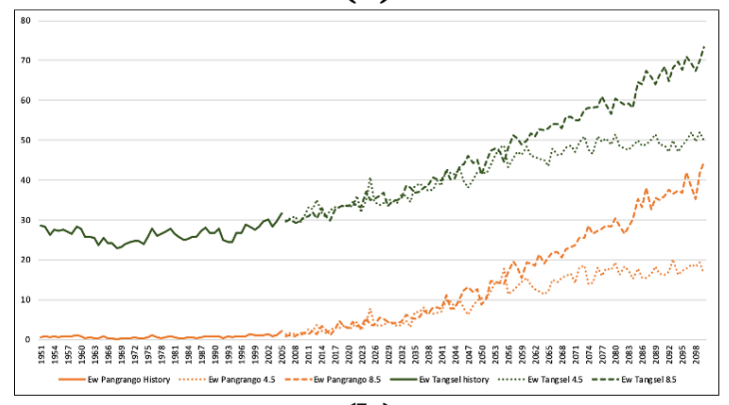

(b)

Figure 3. (a) The Time Series of CDD from 1951-2100; (b) The Time Series of $\mathrm{E}_{w}$ from 1951-2100.

riod while the CDD at Pangrango is only around 20 degreedays. The trend in the next period (2006-2100) is shown in two scenarios, RCP4.5 and RCP8.5. RCP4.5 time series shows rapid increasing trend from 2005-2050 then the trend is somehow no longer as rapid as the previous trend in the period 2050-2100. The graph shown by RCP8.5 scenario is different. It shows similar rapid positive trend but does not stop in 2050. In the other hand, the positive trend is persistently rapid for the period 2050-2100. Therefore, in the mid-century both RCP4.5 and RCP8.5 show similar CDD values while in the end of century those scenarios show different values. In Tangsel, RCP4.5 shows CDD in 2100 around 1,900 degree-days and RCP8.5 around 2,700 degree-days, while in Pangrango, RCP4.5 shows CDD around 600 degree-days and RCP8.5 around 1,700 degree-days.

Figure $3 \mathrm{~b}$ shows the linear relationship between $\mathrm{E}_{w}$ and CDD in both sample grids. The cooling energy needed in Tangsel shows no significant trend during baseline period as well as in Pangrango with the difference in $\mathrm{E}_{w}$ is approximately $30 \mathrm{kWh} / \mathrm{m}^{2}$ year. In both sample grids, both of RCP4.5 and RCP8.5 show significant increase in $\mathrm{E}_{w}$ from 2005 to 2050. Moreover, after 2050, RCP4.5 shows only slight increase and RCP8.5 keep showing rapid increase in $\mathrm{E}_{w}$ in both grids. In Pangrango, RCP4.5 simulation gives $\mathrm{E}_{w}$ around $30 \mathrm{kWh} / \mathrm{m}^{2}$ year in 2100 , while RCP8.5 gives around 18 $\mathrm{kWh} / \mathrm{m}^{2}$ year. Meanwhile, in Tangsel, RCP4.5 projects $\mathrm{E}_{w}$ around $75 \mathrm{kWh} / \mathrm{m}^{2}$ year in 2100 , while RCP8.5 around 50 $\mathrm{kWh} / \mathrm{m}^{2}$ year. 

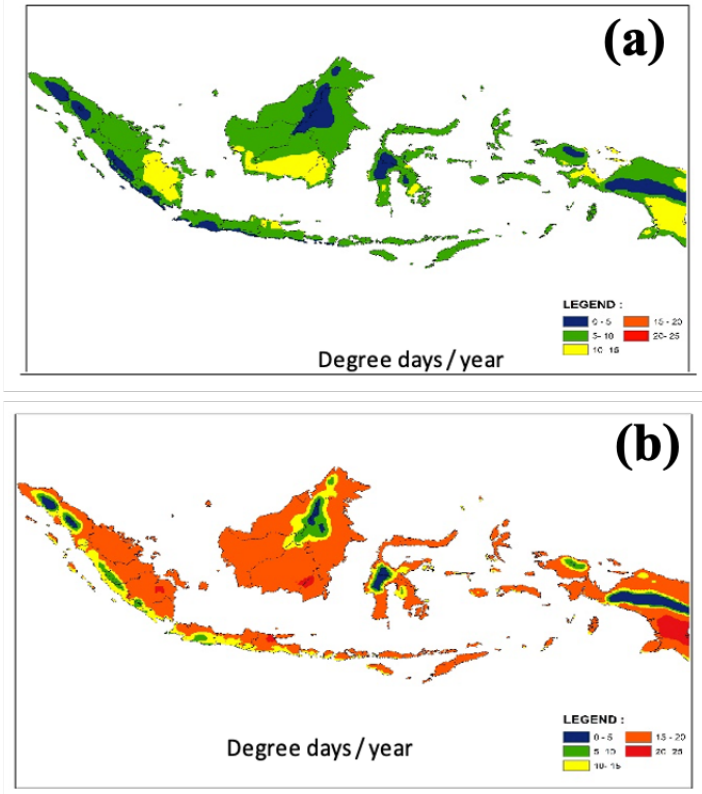

Figure 4. The CDD Trends for 2006-2100 Period Based on: (a) RCP4.5 and (b) RCP8.5.

\subsection{CDD Trends Based on RCP4.5 and 8.5 Simulation} As shown in Figure 4a, the CDD trends for 2006-2010 period based on RCP4.5 scenario increase between 10 to 15 degree-days/year in south-eastern Sumatra, south Kalimantan, north-eastern Java, west Papua and south Papua. Meanwhile, lower increase in trends shown mostly in mountains area in the middle part of Sumatra, Kalimantan, Sulawesi, Papua and in southern Java.

Figure $4 \mathrm{~b}$ shows higher increase in $\mathrm{CDD}$ trends based on RCP8.5 than RCP4.5. Highest positive trends value approximately from 20 to 25 degree-days/year that occurred in most parts of the Islands in Indonesia except the middle part that shows lower increase in CDD. Same as shown in Figure 4a, the highland and mountains areas dominate the area of lowest increase in CDD trends based on RCP8.5 with the value from 0 to 5 degree-days/year. Largest area with the highest positive increase in CDD is Kalimantan, while the largest area with the lowest one is middle part of Papua.

\section{4 $\mathrm{E}_{w}$ Trends Based on RCP4.5 and 8.5 Simulations}

Similar trends pattern as in CDD, also shown in Figure 5a, the $\mathrm{E}_{w}$ trends for 2006-2010 period based on RCP4.5 scenario have the highest positive value in south-eastern Sumatra, south Kalimantan, north-eastern Java, west Papua and south Papua. Meanwhile, lower increase in trends shown mostly in mountains area in the middle part of Sumatra, Kalimantan, Sulawesi, Papua and in southern Java with more than $0.5 \mathrm{kWh} / \mathrm{m}_{2}$ per year.

Figure $5 \mathrm{~b}$ shows higher increase in $\mathrm{E}_{w}$ trends based on RCP8.5 than RCP4.5. Highest positive trends mostly occurred in low altitude area of the Islands, while the highland and moun-

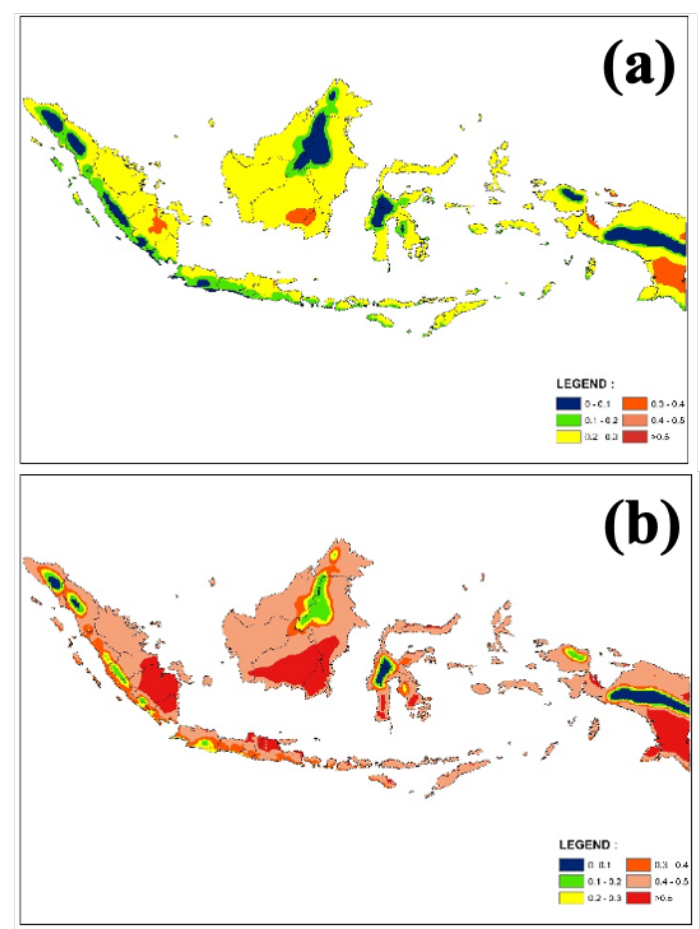

Figure 5. The $\mathrm{E}_{w}$ Trends for 2006-2100 Period Based on: (a) RCP4.5 and (b) RCP8.5.

tains areas in central parts of major Islands still dominate the area of lowest increase in $\mathrm{E}_{w}$.

\subsection{The Difference of Energy Demand for Air Condition- ing System $\left(\mathrm{E}_{w}\right)$ in 2050 and 2100 to Mean Energy Demand $\left(\mathrm{E}_{w}\right)$ 1950-2005}

For technical use, it is important to know the change of $\mathrm{E}_{w}$ in mid-century (2050) and end-century (2100). Therefore, the change between those periods is calculated. The calculation is simply estimating the difference of $\mathrm{E}_{w}$ in 2050 to mean $\mathrm{E}_{w}$ period 1950-2005 for the change in mid-century and estimating the difference of $\mathrm{E}_{w}$ in 2100 to mean $\mathrm{E}_{w}$ period 1950-2005 for the change in end-century. The results for the entire area of Indonesia are mapped in Figure 6.

As shown on the map, the changes in 2050 and 2100 are positive. In 2050 , both RCP4.5 and RCP8.5 shows similar changes with slightly different pattern. In 2100 , the changes are even higher especially for RCP8.5 scenario. While in 2050 both scenarios show slightly similar pattern, in 2100 the difference between two scenarios are obvious. RCP8.5 scenario clearly shows higher $\mathrm{E}_{w}$ comparing to RCP4.5 scenario. The hotspots of changes in $\mathrm{E}_{w}$ are also clearer for RCP8.5 scenario. This development is on the line with the data example at Pondok Betung Climatological Station, Jakarta. Both scenarios show similar trend till mid-century then RCP4.5 scenario shows weak positive trend while RCP8.5 scenario keeps its pace.

From RCP4.5 scenario, in 2050, the changes in $\mathrm{E}_{w}$ over 


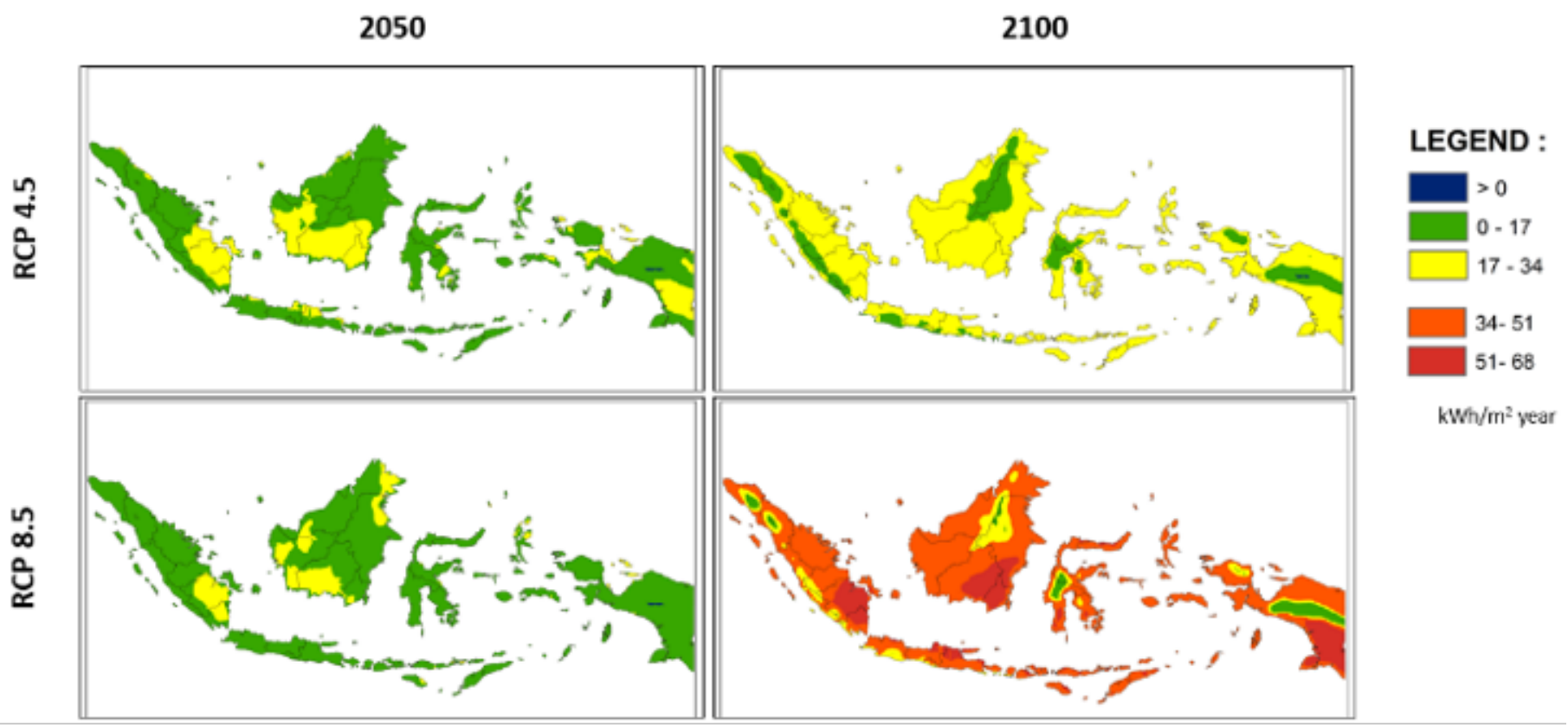

Figure 6. The Difference of Energy Demand for Air Conditioning System $\left(\mathrm{E}_{w}\right)$ in 2050 and 2100 to Mean Energy Demand $\left(\mathrm{E}_{w}\right)$ $1950-2005$

Indonesia are $17 \mathrm{kWh} / \mathrm{m}^{2}$ year or less. Some regions show higher changes, around 17 to $34 \mathrm{kWh} / \mathrm{m}^{2}$ year such as southeastern part of Sumatera, West Borneo, Mid Borneo, South Borneo, Southern part of East Borneo, North Coastal of Java, southern part of South East Sulawesi, some small islands close to Papua, southern part of Papua, and some spots on northern part of Papua. Those areas are also the hotspots of CDD trends for RCP4.5 scenario. In 2100, the changes in $\mathrm{E}_{w}$ are higher. The changes in $\mathrm{E}_{w}$ in most areas of Indonesia are 17 to 34 $\mathrm{kWh} / \mathrm{m}^{2}$ year. Only some small areas have changes less than $17 \mathrm{kWh} / \mathrm{m}^{2}$ year such as Mountains Barisan, southern part of Java, Bali and Lombok, northern part of Borneo, middle part of Sulawesi, north-eastern part of Papua, and Mountains Jaya Wijaya. Most of those areas are mountains and high lands.

Based on the RCP8.5 scenario, in 2050, the change of $\mathrm{E}_{w}$ in most of Indonesia area is also less than $17 \mathrm{kWh} / \mathrm{m}^{2}$ year. However, the hotspots are different. RCP8.5 scenario shows less hotspots which changes are 17 to $34 \mathrm{kWh} / \mathrm{m}^{2}$ year such as Lampung, South Sumatera, Southern part of Borneo, some spots on East and North Borneo, and some small islands close to Papua. In 2100, the change of $\mathrm{E}_{w}$ for RCP8.5 scenario more or less double the change of $\mathrm{E}_{w}$ for RCP4.5 scenario. Most Indonesia areas changes 34 to $51 \mathrm{kWh} / \mathrm{m}^{2}$ year by 2100 . The area in mountains and highlands changes less than 34 $\mathrm{kWh} / \mathrm{m}^{2}$ year such as Mountains Barisan, Mountains Jaya Wijaya, north-eastern part of Papua, in the middle of Sulawesi, some northern part of Borneo and southern part of West Java. Some areas are the hotspots for the change in $\mathrm{E}_{w}$, changes more than $51 \mathrm{kWh} / \mathrm{m}^{2}$ year by 2100 which are south-eastern part of Sumatera, south-eastern part of Borneo, northern part of East Java, and Southern part of Papua.

\section{CONCLUSIONS}

This study applies CDD concept into CORDEX-SEA data to find out the influence in climate change to cooling energy demand in Indonesia. It is also used to understand more about the change in energy demand in the near future and far future. After studying the conditions in Indonesia to derive the relationship between CDD and $\mathrm{E}_{w}$ in Indonesia, it is found out that the relationship of both is linear. It is due to the fact that most buildings in Indonesia have no insulations. This leads to inefficient use of the energy needed for cooling; hence, more energy is needed to cool a space. This condition can be improved by applying insolation to buildings, however, the cost efficiency to build this kind of wall is still need to be studied.

From the mean CDD and $\mathrm{E}_{w}$ in Indonesia (Figure 2a and Figure 2b), it can be seen that cooling energy demand in Indonesia is highly related to topography. Coastal area and small islands tend to have the highest cooling energy demand while mountains area tend to have lowest energy demand. In fact, the most populated major cities in Indonesia are at or close to coastal area, for example: Jakarta, Denpasar, Surabaya, and Makassar. This means most people live in the area where the energy demand for cooling is high. With the growing use in air conditioning system, it is estimated the total use of cooling energy of the country will also grow, especially in big cities.

In tropics, warming is a substantial part which can increase the amount of energy needed for cooling. The application of two scenarios from CORDEX-SEA shows positive trends in both CDD and $\mathrm{E}_{w}$ (Figure $4 \mathrm{a}-\mathrm{b}$, Figure $5 \mathrm{a}-\mathrm{b}$ ). From these re- 
sults, it is safe to say that climate change will cause and increase in energy demand for cooling in Indonesia. However, RCP4.5 clearly shows lower trend comparing to RCP8.5. The way we solve the climate change problem will influence the amount of energy we need to use in the future. Therefore, Climate change mitigation strategy should be taken seriously.

In 2050 RCP4.5 shows slightly higher $\mathrm{E}_{w}$ than RCP8.5 in some regions. However, in 2100 , RCP8.5 shows significantly higher energy consumption for air conditioning system. The eastern part of Middle Kalimantan, South Kalimantan, Southern part of East Kalimantan, Northern East Java, Northern part of Lampung, South Sumatera, and Southern part of Papua shows the highest changes ( 51 to $68 \mathrm{kWh} / \mathrm{m}^{2}$ year)

\section{ACKNOWLEDGEMENT}

We thank to the Head of Agency, Meteorology Climatology and Geophysics of Republic of Indonesia (BMKG) for the CORDEX-SEA datasets. Further thanks to the Board member of School for Meteorology, Climatology and Geophysics (STMKG) for their support in this research.

\section{REFERENCES}

Arifwidodo, S. D., Chandrasiri, O., Abdulharis, R, and Kubota, T. (2019). Exploring the effects of urban heat island: A case study of two cities in Thailand and Indonesia. In $A P N$ Science Bulletin

Arifwidodo, S. D., Ratanawichit, P, and Chandrasiri, O (2021). Understanding the implications of urban heat island effects on household energy consumption and public health in Southeast Asian cities: evidence from Thailand and Indonesia. In Springer: Singapore. 33-42

Assawamartbunlue, K. (2013). An investigation of cooling and heating degree-hours in Thailand. Journal of Clean Energy Technologies, 1(2); 87-90

Atalla, T., Gualdi, S, and Lanza, A.(2018). A global degree days database for energy-related applications Energy, 15(143); 1048-1055

Bodalal, A., S. Mashite, O. Aladouli, and A. Ihdash (2017). Calculation of annual heating and cooling energy requirements for residential building in different climate zones in Libya. Innovative Energy \& Research, 6(2); 2576-1463

Buyunakalaca, O., H. Bulut, and T. Yılmaz (2001). Analysis of variable-base heating and cooling degree-days for Turkey. Applied Energy, 69(4); 269-283

Intergoverment Panel Climate Change (2013). Climate Change 2013: The Physical Science Basis. In Cambridge University Press: Cambridge and New York

Intergoverment Panel Climate Change (2014a). In Climate Change 2014: Synthesis Report. Contribution of Working Groups I, II and III to the Fifth Assessment Report of the Intergovernmental Panel on Climate Change, Core Writing Team, Pachauri RK, Meyer LA (eds) In Intergoverment Panel Climate Change: Geneva, Switzerland. 151

Intergoverment Panel Climate Change (2014b). In Climate
Change 2013: The Physical Science Basis. Contribution of Working Group I to the Fifth Assessment Report of the Intergovernmental Panel on Climate Change, Stocker TF, Qin D, Plattner G-K, Tignor M, Allen SK, Boschung J, Nauels A, Xia Y, Bex V, Midgley PM (eds) In Cambridge University Press: Cambridge, UK and New York. 1535

James, G. (2008). Reducing The Carbon Output of A Modern Commercial Building. Gary James Crosscount Environmental Engineering Press

Kementerian Energi dan Sumber Daya Mineral (2018). Electicity Statistic 2017. 31th edition. (in Indonesia)

National Bureau of Statistics of China(2013). China Energy Statistical Yearbook 2013. China Statistics Press (in Chinese). Ngo-Duc, T., Tangang, F. T., Santisirisomboon, J., Cruz, F., Trinh-Tuan, L., Nguyen-Xuan, T., Phan-Van, T., Juneng, L., Narisma, G., Singhruck, P, and Gunawan, D (2017). Performance evaluation of RegCM4 in simulating extreme rainfall and temperature indices over the CORDEX-Southeast Asia region International Journal of Climatology, 37(3); 16341647

Nguyen-Thuy, H., Ngo-Duc, T., Trinh-Tuan, L., Tangang, F., Cruz, F., Phan-Van, T., Juneng, L., Narisma, G., Santisirisomboon, J (2021). Time of emergence of climate signals over Vietnam detected from the CORDEX-SEA experiments International Journal of Climatology, 41(3); 1599-1618

Rehman, S., L. M. Al-Hadhrami, and S. Khan (2011). Annual and seasonal trends of cooling, heating, and industrial degree-days in coastal regions of Saudi Arabia. Theoretical and Applied Climatology, 104(3); 479-488

Shanmugapriya, S., M. Premalatha, S. Rajkumar, and I. Thirunavukkarasu (2011). Analysis of Colling Degree Days for Tiruchirappalli-A District In India. International Journal of Research and Reviews in Applied Sciences, 8(1); 4456

Spinoni, J., J. V. Vogt, P. Barbosa, A. Dosio, N. McCormick, A. Bigano, and H.-M. Füssel (2018). Changes of heating and cooling degree-days in Europe from 1981 to 2100 . International Journal of Climatology, 38; 191-208

Siyak, M (2009). Potential energy demand for cooling in the 50 largest metropolitan areas of the world: Implications for developing countries Energy Policy, 37(4); 1382-1384

Stocker, T. (2014). Climate change 2013: the physical science basis: Working Group I contribution to the Fifth assessment report of the Intergovernmental Panel on Climate Change. Cambridge University Press

Tangang, F., L. Juneng, F. Cruz, G. Narisma, J. Dado, T.P. Van, T. Ngo-Duc, L. Trinh-Tuan, T. Nguyen-Xuan, J. Santisirisomboon, et al. (2015). The southeast Asia regional climate downscaling (SEACLID)/CORDEX southeast Asia project and the results of its sensitivity experiments of RegCM4 cumulus and ocean fluxes parameterization schemes on temperature and extremes. In General Assembly Conference Abstracts; 7853

Tangang, F., Chung, J. X., Juneng, L., Salimun, E., Ngai, S. T., Jamaluddin, A. F., Mohd, M. S., Cruz, F., Nar- 
isma, G., Santisirisomboon, J., Ngo-Duc, T (2020). Projected future changes in rainfall in Southeast Asia based on CORDEX-SEA multi-model simulations Climate Dynamics, 55(1); 1247-1267

Thevenard, D (2011). Methods for estimating heating and cooling degree-days to any base temperature Ashrae Transactions, 117(1); 884-892

Thom, H. (1952). Seasonal degree-day statistics for the United States. Monthly Weather Review, 80(9); 143-147

Thom, H. C. S. (1954). The rational relationship between heating degree days and temperature. Monthly Weather Review,
82(1); $1-6$

Thomson, A. M., K. V. Calvin, S. J. Smith, G. P. Kyle, A. Volke, P. Patel, S. Delgado-Arias, B. Bond-Lamberty, M. A. Wise, L. E. Clarke, et al. (2011). RCP4. 5: a pathway for stabilization of radiative forcing by 2100 . Climatic Change, 109(1); $77-94$

Wibig, J. (2003). Heating degree days and cooling degree days variability in Lodz in the period 1931-2000. In Fifth International Conference on Urbun Climate. Lodz, Poland. 471474 